No.1

\title{
Predicting Gamma Ray Linear Attenuation Coefficient for Different Nano- Concrete Types Using Artificial Intelligence
}

\author{
Islam N. Fathy ${ }^{1}$, Alaa A. El-Sayed ${ }^{2}$, Waleed H. Sufe ${ }^{3}$
}

1 B.SC faculty of engineering, Fayoum University. Assistant Lecturer at OHI, Egypt

2 Associate Professor of Structural Engineering, Faculty of Engineering, Fayoum University, Egypt

3 Professor in chemistry, Housing and Building National Research Center, Cairo, Egypt

Corresponding author mail: islamnabil371@gmail.com

\begin{abstract}
Fire in buildings is nearly always man- made, i.e. resulting from negligence or error, which can cause immense damage in terms of lives and property [1]. But when we deal with nuclear constructions (like nuclear power plants NPP), the dangers of fire do not stop only at the potential damage that the concrete structure is exposed to, but rather extends to the risk of a radiation leak that may cause serious damage to the human life and all living creatures. For this reason, designers of nuclear constructions (which are mostly reinforced concrete) give special attention for making the concrete structure capable of resisting the effects of fire or thermal leakage, as well as having a high ability to resist all types of radiation (specially gamma ray radiation). On the other hand, incorporation of nano additives into concrete structures components become a promising field of research these days. The current study tries to investigate the effect of using different nano materials (Nano silica, Nanoclay, and hybrid mix of both materials) as a cement replacement into the concrete radiation resistance ability (in the term of linear attenuation coefficient $\mu$ ). Results showed remarkable enhancement on the values of $\mu$ at all temperature degrees. For the conduct of reliable estimate and prediction of the values $\mu$, this study adopts the fuzzy logic models as powerful tools of artificial intelligence to model the non-linear cause and effect relationships. Prediction results was superior when compared with traditional linear regression analysis.
\end{abstract}

Key Words: Nanoparticles, linear attenuation coefficient, Fuzzy logic models, Artificial intelligence. 1.Introduction

Concrete is widely used as a construction material due to its different advantages, such as the high strength, workability, and durability properties (corrosion, fire, and radiation resistance ability). As a result of these advantages, concrete is the basic and most important material in the process of building nuclear power plants NPP. Usually heavy weight concrete is the most popular concrete type to use in the construction of NPP due to its high ability to resist radiation compared to the other types of concrete. However, this advantage can be achieved by using ordinary concrete supported by some additives that enable it to reach a high capacity, whether in resistance to fire or radiation. Nanotechnology opened a world of modern materials with unique characteristics that made it represents a scientific revolution in the world of building materials technology and all branches of science and manufacturing technologies. Nanosilica, Nanoclay, Nano carbon tubes, and many other Nanomaterials were investigated for application in concrete industry. On the other hand, there is a problem that scientists and engineers always face when dealing with concrete, which is the inability to predict its behavior due to the large number of variables that control the results of any characteristic of concrete such as compressive strength, residual strength after fire exposure, or radiation shielding ability. Hence the idea of using artificial intelligence applications to overcome these obstacles has come. Fuzzy Logic Systems FLS which considered as a strong tool of artificial intelligence techniques were used for the conduct of reliable estimate of the complex nonlinear behaviour of concrete gamma ray linear attenuation coefficient $\mu$ after fire exposure. The Fuzzy system modelling approach is simpler and more direct than traditional statistical methods, particularly when 
modelling nonlinear multivariate interrelationships. Artificial Intelligent-based modelling techniques like Fuzzy system models have been utilized to approximate non-linear and complex behaviour for various properties of construction materials. [2]. A general fuzzy system is presented in Figure (1). According to Figure (1), the system has basically four components: fuzzification, fuzzy rule base, fuzzy output engine, and defuzzification [3]. Fuzzification converts each piece of input data to degrees of membership by a lookup in one or more several membership functions. Fuzzy rule base contains rules that include all possible fuzzy relation between inputs and outputs. These rules are expressed in the IF-THEN The key idea in fuzzy logic, in fact, is the allowance of partial belongings of any object to different subsets of a universal set instead of belonging to a single set completely. Partial belonging to a set can be described numerically by a membership function, which assumes values between 0 and 1 inclusive. Intuition, inference, rank ordering, angular fuzzy sets, neural networks, genetic algorithms, and inductive reasoning can be, among many, ways to assign membership values or functions to fuzzy variables. Fuzzy membership functions may take many forms, but in practical applications, simple linear functions, such as triangular ones, are preferable. In the current FLS model, different conditions from temperature degree, nanoparticles type, and replacement ratios are represented major data inputs, while the predicted value of $\mu$ after fire exposure represent the model output.

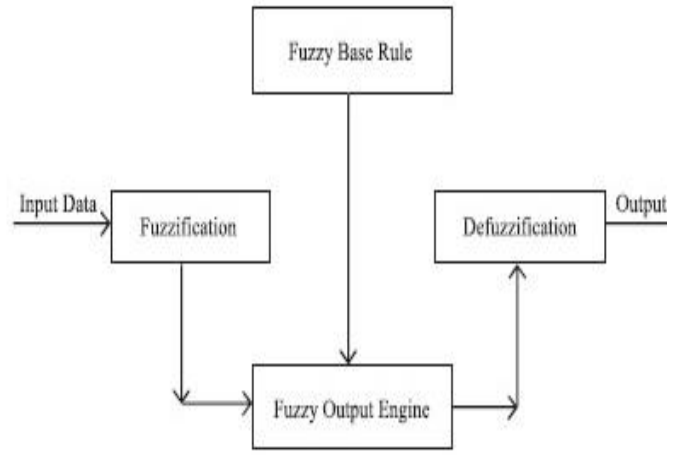

Figure (1) The fuzzy logic modelling process.

\section{The aim of study}

In the current study, the experimental work focused on the effects of adding Nanosilica, Nanoclay, and hybrid mix of the two materials into normal concrete composition in order to improve its ability to resist radiation and high temperature. In another words, the current investigation aims to explore the ability of normal strength concrete supported with Nanoadditives to replace the heavy concrete as a construction material in the structures exposed to radiation and high temperature effects. There are different methods to detects the ability of different materials to resist radiation. In that study, linear attenuation coefficient calculated from Beer lambert equation was adopted to determine the ability of the different concrete mixes to absorb the gamma ray radiation. Beer lambert formulate the general law to calculate the value of linear attenuation coefficient: $\mu=$ $\frac{1}{t} \ln \left(\frac{I 0}{I}\right)$, where $\mu$ is the linear attenuation coefficient, $t$ is the thickness of the shield material, I0 represent the initial intensity of gamma rays emits from the radiation source without using the shield material, and I represent the final intensity of gamma rays emits from the radiation source after using the shield material. The higher the value of the linear attenuation coefficient is, the higher the material's ability to resist radiation. Moreover, the current study adopted Fuzzy Logic Systems models as a strong Artificial Intelligence tool in order to develop smart prediction model of the value of gamma ray linear attenuation coefficient $\mu$ at different conditions of temperature degrees, Nano addition type, and Nano addition proportion.

To assure and verify the high prediction accuracy of the developed Fuzzy Logic model, prediction results were compared to the results of linear regression analysis. Regression analysis is a set of statistical processes for estimating the relationships among variables [4]. It includes many techniques for modeling and analysing several variables, when the focus is on the relationship between a dependent variable and one or more variables. Regression analysis is widely used for prediction and forecasting, where its use has substantial overlap with the 
field of machine learning. Regression analysis is also used to understand which among the independent variables are related to the dependent variable, and to explore the forms of these relationships. The performance of regression analysis methods in practice depends on the form of the data generating process, and how it relates to the regression approach being used [5].

In addition to the verification process of the proposed FLS model, sensitivity analysis of the model variables was performed. Sensitivity analysis (SA) usually used to determine which subset of input factors accounts for most of the output variance and in what percentage. Sensitivity Analysis can be explained as how much the model response is influenced by changes in the model input parameters [6]. To assess the impact of each of the key four input parameters on gamma ray linear attenuation coefficient, a Sensitivity Analysis was performed using Statistical Package for the Social Sciences software (SPSS).

\section{Experimental work}

Recently, many of Pozzolanic materials with particles in nano size available in the local market were proposed to be used in enhancing the properties of cementitious mixes (cement pastes, cement mortar and concrete). Nano silica(NS) and Nano clay (NC) are the two nanomaterials widely used in concrete construction sector. Also, some previous studies proposed using the hybrid of them for the same purpose. To achieve the targets of the current research, the experimental program was designed to cover a wide range of variables changing in order to provide sufficient amount of data to build up the FLS model. At concrete curing age of 28 days, specimens of different mixes were tested to calculate the gamma ray linear attenuation coefficient values at room conditions, and with different temperatures $\left(200^{\circ} \mathrm{C}, 400^{\circ} \mathrm{C}, 600^{\circ} \mathrm{C}, 800^{\circ} \mathrm{C}\right)$, and exposure time of two hours. The results of $\mu$ of 65 cubic specimens of $10 \times 10 \times 10 \mathrm{~cm}$ represents the input data of the Fuzzy Logic prediction model. All used materials description, mixes proportions, and tests criteria and results are provided in the following sections.

\section{1 used materials}

\subsection{1 cement}

In this study, CEM I $42.5 \mathrm{~N}$. Testing of cement was carried out as the Egyptian Standard Specifications ESS 4756-1/2009 [7], with specific gravity of 3.15 . The properties of the used cement are shown in Table (1).

Table (1) properties of the used cement.

\begin{tabular}{|c|c|c|}
\hline Property & Value & ESS Limits \\
\hline $\begin{array}{c}\text { Specific } \\
\text { gravity }\end{array}$ & 3.15 & ------ \\
\hline $\begin{array}{c}\text { IS time } \\
\text { (min) }\end{array}$ & 198 & $>60 \mathrm{~min}$ \\
\hline FS time & 256 & $<600 \mathrm{~min}$ \\
\hline Fineness \% & $7 \%$ & $<10 \%$ \\
\hline $\begin{array}{c}\text { Soundness } \\
(\mathrm{mm})\end{array}$ & 3 & $<10 \mathrm{~mm}$ \\
\hline
\end{tabular}

The chemical composition of used cement shown in Table (2).

Table (2) Chemical Composition of cement

\begin{tabular}{|c|c|}
\hline Oxide Composition & $\begin{array}{c}\text { CEMI By } \\
\text { Mass \% }\end{array}$ \\
\hline Silicon dioxide $(\mathrm{SiO} 2)$ & 20.24 \\
\hline Aluminum oxide $(\mathrm{Al} 2 \mathrm{O} 3)$ & 6.09 \\
\hline Ferric oxide $(\mathrm{Fe} 2 \mathrm{O} 3)$ & 3.38 \\
\hline Calcium oxide $(\mathrm{CaO})$ & 62.65 \\
\hline Magnesium oxide $(\mathrm{MgO})$ & 2.03 \\
\hline Sulphur trioxide $(\mathrm{SO} 3)$ & 2.24 \\
\hline Potassium oxide $(\mathrm{K} 2 \mathrm{O})$ & 0.87 \\
\hline Titanium dioxide $(\mathrm{TiO} 2)$ & - \\
\hline Sodium oxide $(\mathrm{Na} 2 \mathrm{O})$ & 0.78 \\
\hline Loss on Ignition & 1.68 \\
\hline
\end{tabular}

\subsubsection{Fine Aggregate}

Fine aggregate used in concrete cubes mixing are natural clean siliceous sand with specific gravity of 2.64. The physical properties of sand including specific weight, bulk density, and percentage of silt and fine impurities are shown in Table (3).

Table (3) Physical properties of fine aggregate

\begin{tabular}{|c|c|c|}
\hline Test & $\begin{array}{c}\text { Siliceous } \\
\text { Sand }\end{array}$ & Limits \\
\hline
\end{tabular}




\begin{tabular}{|c|c|c|}
\hline $\begin{array}{c}\text { Specific } \\
\text { Gravity }\end{array}$ & 2.65 & ------- \\
\hline $\begin{array}{c}\text { Bulk Density } \\
(\mathrm{t} / \mathrm{m} 3)\end{array}$ & 1.70 & ------- \\
\hline $\begin{array}{c}\text { Fineness } \\
\text { Modulus }\end{array}$ & 2.92 & ------- \\
\hline $\begin{array}{c}\text { Materials } \\
\text { Finer than } \\
200 \text { Sieve } \\
\text { (No.\%) }\end{array}$ & 2.6 & $\begin{array}{c}\text { Less than } \\
3 \%\end{array}$ \\
\hline
\end{tabular}

Sieve analysis of the used fine aggregate illustrated in Table 4. All values lie within the range of fine grading zone according to the classification of the Egyptian code of practice for design of concrete structures [8], and the requirement of ESS 1109/2002 [9].

Table (4) Sieve analysis of fine aggregates

\begin{tabular}{|c|c|}
\hline Sieve Size (mm) & \% Passing \\
\hline 4.75 & 95.2 \\
\hline 2.8 & 91.6 \\
\hline 1.4 & 77.3 \\
\hline 0.71 & 57.2 \\
\hline 0.355 & 13.8 \\
\hline 0.177 & 1.9 \\
\hline
\end{tabular}

\subsubsection{Coarse Aggregate}

Coarse aggregate used at this experimental study was local crushed limestone (dolomite) with a specific gravity of 2.66, bulk unit weight of 1618 $\mathrm{Kg} / \mathrm{m} 3$, void percentage $39.2 \%$, fineness modulus of 6.35 , according to the requirement of ESS 1109/2002 [9].

\subsubsection{Water}

Tap water was used for both mixing and curing the test specimens according to the requirement of the (ECP 203-2007) [8].

\subsubsection{Nano Silica}

In this study amorphous Nanosilica ( $\mathrm{SiO} 2)$ with particle size ranged from 15-80 nm was used in preparation of the Nanosilica blended concrete specimens. The Nanosilica used is powder type, Colorless (White), and with average density 2.2 - $2.6 \mathrm{~g} / \mathrm{mL}$ at $25{ }^{\circ} \mathrm{C}$ as shown in Figure (2). Transmission Electron Microscope (TEM) micrograph of Nanosilica used in this study are shown in Figure (3).

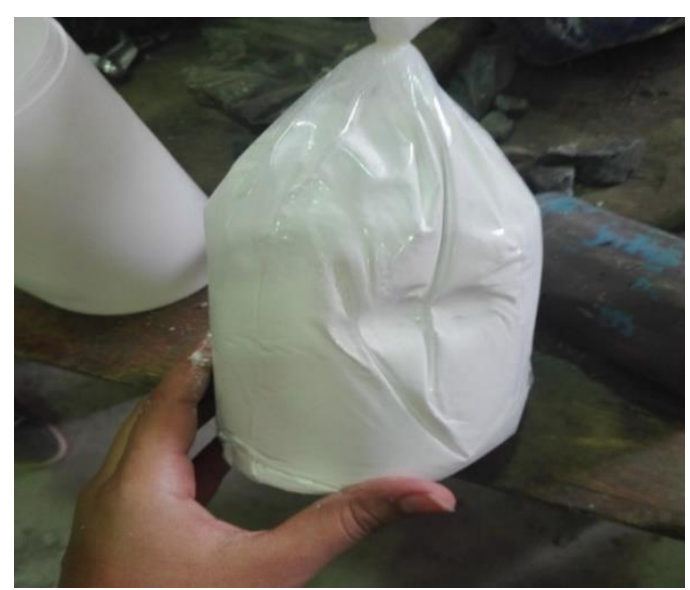

Figure (2) Nano silica used in this research work

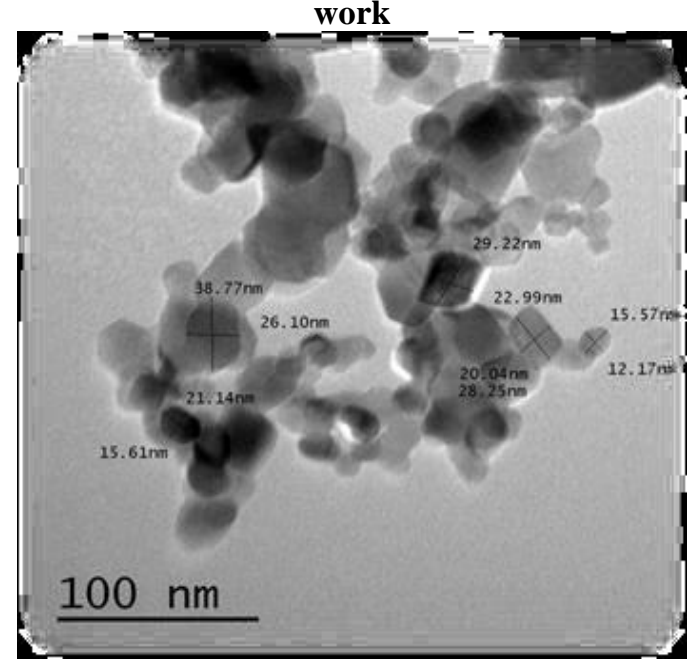

Figure (3) TEM micrograph for the Nano silica.

Table (5) Chemical Composition of Nano silica

\begin{tabular}{|c|c|}
\hline Composition & \% of mass \\
\hline $\mathrm{SiO} 2$ & 99.86 \\
\hline $\mathrm{Al} 2 \mathrm{O} 3$ & 0.02 \\
\hline $\mathrm{CaO}$ & 0.03 \\
\hline $\mathrm{Fe} 2 \mathrm{O} 3$ & 0.01 \\
\hline $\mathrm{TiO} 2$ & 0.01 \\
\hline Loss on Ignition & 0.05 \\
\hline
\end{tabular}

\subsubsection{Nanoclay}

The Nano-clay used in this work is Nano Metakaolin which produced from heat treatment 
of kaolin. This heat treatment, at about $900{ }^{\circ} \mathrm{C}$, and (5) respectively. Breaks down the structure of kaolin such that the alumina and silica layers become puckered and lose their long-term order, producing Nano Metakaolin MK. The Nanoclay used is powder with (off white) color, and with average density of $0.6-0.8 \mathrm{gm} / \mathrm{cm} 3$ at 25 ${ }^{\circ} \mathrm{C}$. The appearance of a sample of Nanoclay used for this research study and its TEM micrograph are shown in Figures (4)

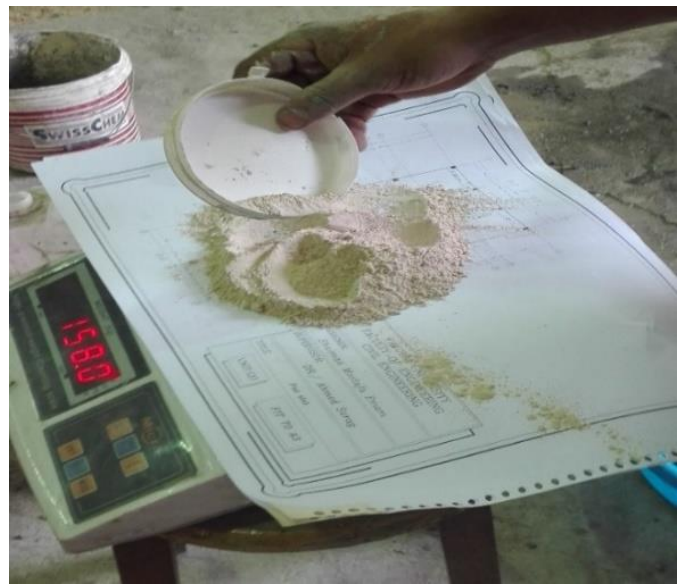

Figure (4) Nano clay used in this study

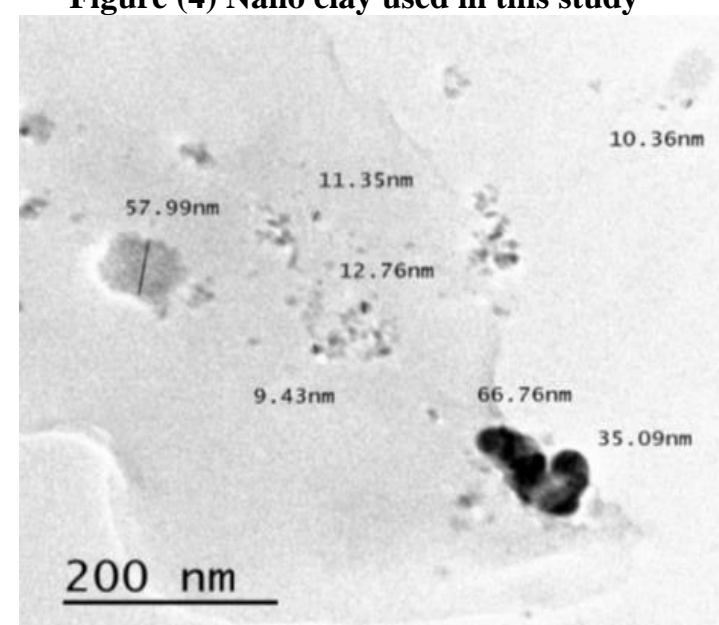

Figure (5) TEM micrograph of for Nano clay particles
Table (6) Chemical Composition of Nano clay

\begin{tabular}{|c|c|}
\hline Composition & \% of mass \\
\hline $\mathrm{SiO} 2$ & 51.52 \\
\hline $\mathrm{Al} 2 \mathrm{O} 3$ & 40.18 \\
\hline $\mathrm{CaO}$ & 2.00 \\
\hline $\mathrm{Fe} 2 \mathrm{O} 3$ & 1.23 \\
\hline $\mathrm{TiO} 2$ & 2.27 \\
\hline Loss on Ignition & 2.01 \\
\hline
\end{tabular}

\subsubsection{Hybrid Nano silica - Nano clay}

Hybrid Nano silica - Nano clay is a composition resulting from mixing the two Nanomaterials to obtain improved characteristics as compared to those relevant to each individual component. Previous studies have shown that Nanosilica is more amorphous than Nanoclay so, it has more contribution in increasing of the C-S-H gel during the hydration process of cement [10]. On the other hand, other previous researches have indicated that Nanoclay acts as a filler material having better effect than Nanosilica in decreasing the voids and producing denser concrete [11]. Accordingly, a hybrid mix of (NS+NC) may contribute positively in producing denser, stronger, and less voids concrete. These characteristics may have a good effect on the values of gamma ray linear attenuation coefficient $\mu$.

\subsubsection{Chemical Admixture}

One type of chemical admixtures was used. A superplasticizer based on a modified polycarboxylic ether was employed to obtain a satisfactory workability for the mixes and accelerates the cement hydration. A commercial superplasticizer (GLENIUM ACE 30) produced by chemicals company (BASF) in Egypt was used at all mixes with fixed proportion by $2.77 \%$ by weight of water as recommended percentage by the manufacturer was $1-3 \%$.

\subsection{Mixing properties}

To achieve the objectives of this work, three groups with a total numbers of 12 concrete mixes in addition to control mix were prepared and investigated. The first group was designed using different ratios of Nanoclay as a cement 
replacement with percentages $1,3,5,7,9 \%$. The second group with different ratios of Nanosilica as a cement replacement with percentages 1,2 , 3 , and $4 \%$. The third group with hybrid mix between Nano silica and Nano clay using different ratio, and to answer about the question why that hybrid mix was investigated, the answer is related about characteristics of each material. Previous studies showed that Nano silica is more amorphous than the Nano clay, which means that Nano silica is very effective and contribute in increasing of the C-S-H gel during the hydration process of cement [12]. However, Nano clay can be classified as filler material that help in making concrete dense and durable by decreasing voids ratio [13]. Thence, design combination between Nano silica and Nano clay can make a moderate area between the two materials. Fixed proportion with five liters for each one cubic meters of concrete of chemical additive of Superplasticizer was used to obtain a satisfactory workability for the mixes and accelerates the cement hydration. Constant contents of cement, water, and aggregate, in all concrete mixes, were contemplated to achieve comparable results that reflect the effect of adding different levels of Nanoparticles. The compositions of the concrete mixtures are shown in Table (7).

Table (7) The mixes design

\begin{tabular}{|c|c|c|c|c|c|c|c|c|}
\hline \multirow{3}{*}{ 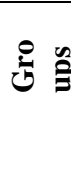 } & \multirow[t]{2}{*}{ Mix } & \multirow{2}{*}{$\begin{array}{c}\text { Symb } \\
\text { ol }\end{array}$} & \multirow{2}{*}{$\begin{array}{c}\text { Cement } \\
(\mathrm{kg})\end{array}$} & \multicolumn{2}{|c|}{$\begin{array}{c}\text { Aggregate } \\
(\mathbf{k g})\end{array}$} & \multirow{2}{*}{$\begin{array}{c}\text { Water } \\
\text { (lit) }\end{array}$} & \multirow{2}{*}{$\begin{array}{c}\text { Nano } \\
\text { Silica } \\
\text { (kg) }\end{array}$} & \multirow{2}{*}{$\begin{array}{l}\text { Nano } \\
\text { Clay } \\
(\mathrm{kg})\end{array}$} \\
\hline & & & & coarse & fine & & & \\
\hline & $\begin{array}{c}\text { Control } \\
\text { mix }\end{array}$ & M0 & 400 & 1170 & 656 & 180 & ---- & ---- \\
\hline \multirow{5}{*}{ 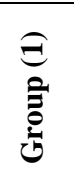 } & $1 \% \mathrm{NC}$ & M1 & 396 & 1170 & 656 & 180 & ---- & 4 \\
\hline & $3 \% \mathrm{NC}$ & M2 & 388 & 1170 & 656 & 180 & ---- & 12 \\
\hline & $5 \% \mathrm{NC}$ & M3 & 380 & 1170 & 656 & 180 & ---- & 20 \\
\hline & $7 \% \mathrm{NC}$ & M4 & 372 & 1170 & 656 & 180 & ---- & 28 \\
\hline & $9 \% \mathrm{NC}$ & M5 & 360 & 1170 & 656 & 180 & --- & 36 \\
\hline \multirow{4}{*}{ 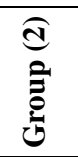 } & $1 \% \mathrm{NS}$ & M6 & 396 & 1170 & 656 & 180 & 4 & --- \\
\hline & $2 \% \mathrm{NS}$ & M7 & 392 & 1170 & 656 & 180 & 8 & ---- \\
\hline & $3 \% \mathrm{NS}$ & M8 & 388 & 1170 & 656 & 180 & 12 & --- \\
\hline & $4 \% \mathrm{NS}$ & M9 & 384 & 1170 & 656 & 180 & 16 & ---- \\
\hline \multirow{3}{*}{ 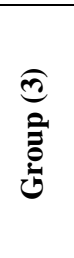 } & $\begin{array}{c}0.5 \% \mathrm{NS}+ \\
4.5 \% \mathrm{NC}\end{array}$ & M10 & 380 & 1170 & 656 & 180 & 2 & 18 \\
\hline & $\begin{array}{c}1 \% \mathrm{NS}+ \\
4 \% \mathrm{NC}\end{array}$ & M11 & 380 & 1170 & 656 & 180 & 4 & 16 \\
\hline & $\begin{array}{c}1.5 \% \mathrm{NS} \\
+ \\
3.5 \% \mathrm{NC}\end{array}$ & M12 & 380 & 1170 & 656 & 180 & 6 & 14 \\
\hline
\end{tabular}

\subsection{Measuring of linear attenuation coefficient $\mu$}

Firstly, it's worth mentioning that the current experimental work represents an extension to previous experiments were performed with the same conditions of materials proportions, temperature degrees, and fire exposure times in order to investigate the positive effects of adding the same nano additives on the value of residual compressive strength of normal strength concrete after fire exposure [1]. At 28 days age, results showed that Nano clay gives the optimum improvement compressive strength in room conditions at 5\% replacement of cement ratio with $17.1 \%$ improvement ration, followed by the hybrid mix at (1\% NS + 4\% NC) with $15 \%$ improvement ratio, and Nano silica at $2 \%$ with $11 \%$ improvement ratio. After fire exposure, The optimum additives ratios for the most of temperature degrees were $5 \%$ for Nano clay, $(1 \%$ $+4 \%$ ) for the hybrid mix., and $3 \%$ for Nano silica. The values of concrete residual compressive strength can give us general view to predict the direction of the expected $\mu$ values. 
In the previous experiments [1], six target temperatures $\left(200^{\circ} \mathrm{C}, 400^{\circ} \mathrm{C}, 500^{\circ} \mathrm{C}, 600^{\circ} \mathrm{C}\right.$, $700^{\circ} \mathrm{C}$, and $800^{\circ} \mathrm{C}$ ) were chosen, besides ambient temperature, to capture the effect of elevated temperature on compressive strength of concrete specimens for exposure times of (60120) minutes with total number of 156 specimens. While the total number of the cubic specimens in the current study was minimized by excluding the temperatures degrees of $\left(500^{\circ} \mathrm{C}, 700^{\circ} \mathrm{C}\right)$, and the exposure time of $(60$ minutes) with total number of 65 specimens. The reason of minimizing the total specimens number is to verify the power of the Fuzzy Logic model to achieve high prediction accuracy with lower available amount of data. The furnace used to simulate the conditions of actual fire exposure is a natural gas furnace, equipped with two net of gas burners, each network contains twenty-one of the gas burners with dimensions of $(400 \times 1300 \mathrm{~mm})$ up to the target temperatures. The outer dimensions of the furnace are $150 \times 120 \times 80 \mathrm{~cm}$ while, the inner dimensions are $140 \times 110 \times 70 \mathrm{~cm}$. The flame was intended to simulate the heating conditions in an actual fire. The concrete specimens were burnt by direct fire flame as shown in Figure (6). Control valves and thermocouples were utilized to control and measure the inside temperature during the firing process. The digital thermometer continuously recorded the temperature as shown in Figure (7).

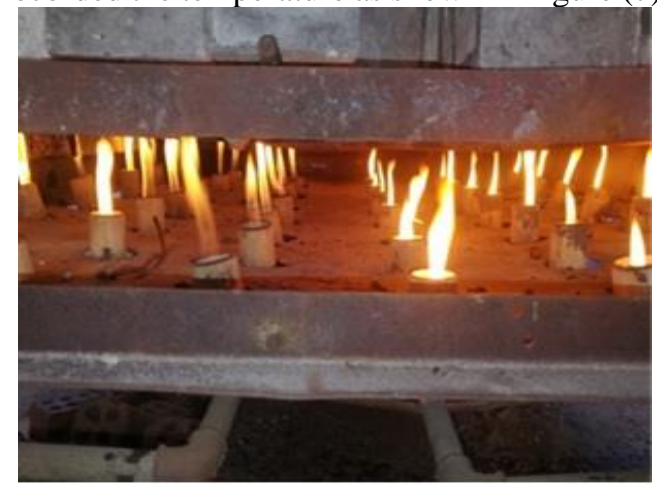

Figure (6) Burning of Concrete specimens

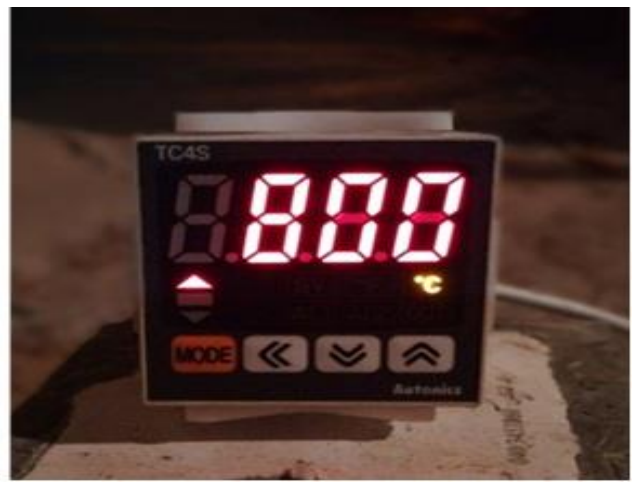

Figure (7) The digital Thermometer

As previously stated, Beer Lambert equation was used to calculate $\mu$ values before and after fire exposure using gamma ray radiation source of Co-60 (1173 keV). The transmitted gamma ray intensity was measured using a gamma-ray spectrometer with Nal detector. Figure (8) illustrates the used technique to detect the concrete shield ability to absorb and resist gamma ray radiation. Firstly, the initial intensity of gamma rays $\mathrm{I} 0$ was measured without using the cubic $10 \times 10 \times 10 \mathrm{~cm}$ concrete shield. Then the different nano concrete shields were put to oppose the way of gamma rays and the intensity of radiation was recalculated $\mathrm{I}$.

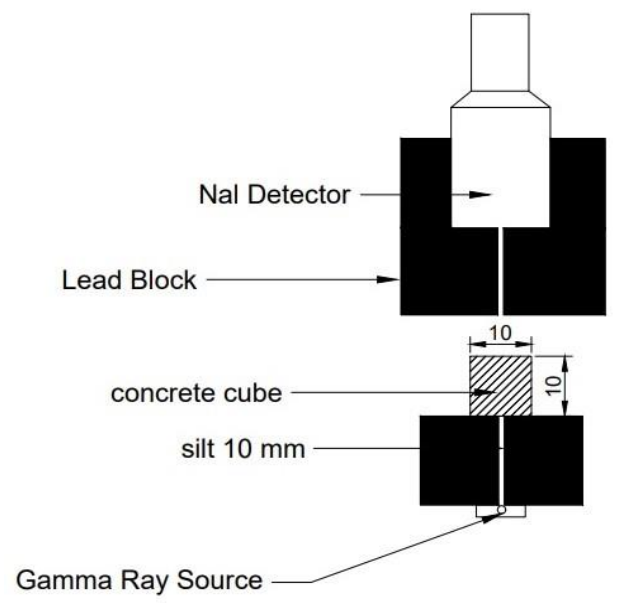

Figure (8) Measuring of $\mu$ for different Nano-concretes

\section{Result and Discussion}

\section{1 linear attenuation coefficient values}

By substituting the measured values of I and I0 in Lambert equation, $\mu$ values were calculated as reported in table (8). Results showing obvious 
improvement in $\mu$ values for the different nanoconcrete specimens, (shaded cells values will be used for prediction process using Fuzzy Logic Systems model later). At the conditions of room temperature, improvement ratios of $(15.8 \%, 14.3 \%$, and $14.3 \%)$ were recorded comparing with the control mix for the optimum nano replacement ratios at $5 \% \mathrm{NC}, 3 \% \mathrm{NS}$, and $(1 \%+4 \%)$ for the hybrid mix. For the different temperature degrees, the improvement ratios varies according to the different mixes and temperatures as illustrated in figure (9) for the optimum replacement proportions.

Table (8) Linear attenuation coefficient $\mu$ results after 2 hour burning.

\begin{tabular}{|c|c|c|c|c|c|c|c|c|c|c|c|c|c|c|}
\hline \multirow{2}{*}{\multicolumn{2}{|c|}{$\begin{array}{c}28 \text { days/2hr } \\
\text { Property }\end{array}$}} & \multirow{3}{*}{ 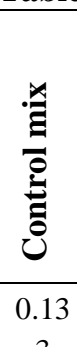 } & \multicolumn{5}{|c|}{ Nano clay (NC)\% } & \multicolumn{4}{|c|}{ Nano silica (NS)\% } & \multicolumn{3}{|c|}{$\begin{array}{c}\text { Hybrid (NS + } \\
\text { NC) } \%\end{array}$} \\
\hline & & & \multirow{2}{*}{$\begin{array}{c}1 \\
\\
0.14 \\
2\end{array}$} & \multirow{2}{*}{$\begin{array}{c}\mathbf{3} \\
0.1 \\
47\end{array}$} & \multirow{2}{*}{$\begin{array}{c}5 \\
0.1 \\
54\end{array}$} & \multirow{2}{*}{$\begin{array}{c}7 \\
0.1 \\
48\end{array}$} & \multirow{2}{*}{$\begin{array}{c}9 \\
0.1 \\
44\end{array}$} & \multirow[b]{2}{*}{$\begin{array}{l}0.1 \\
39\end{array}$} & \multirow{2}{*}{$\begin{array}{c}2 \\
0.1 \\
47\end{array}$} & \multirow{2}{*}{$\begin{array}{c}3 \\
\\
0.1 \\
52\end{array}$} & \multirow{2}{*}{$\begin{array}{c}4 \\
\\
0.1 \\
49\end{array}$} & \multirow{2}{*}{$\begin{array}{c}0.5 \\
+ \\
4.5 \\
0.1 \\
50\end{array}$} & \multirow{2}{*}{$\begin{array}{c}\mathbf{1 + 4} \\
0.1 \\
52\end{array}$} & \multirow{2}{*}{$\begin{array}{c}1.5 \\
+ \\
3.5 \\
0.1 \\
48\end{array}$} \\
\hline \multirow{5}{*}{$\begin{array}{l}\bar{Z} \\
\dot{\Xi} \\
= \\
=\end{array}$} & $\begin{array}{l}25 \\
{ }^{\circ} \mathrm{C}\end{array}$ & & & & & & & & & & & & & \\
\hline & $\begin{array}{c}200 \\
{ }^{\circ} \mathrm{C}\end{array}$ & $\begin{array}{c}0.12 \\
9\end{array}$ & $\begin{array}{c}0.13 \\
9\end{array}$ & $\begin{array}{l}0.1 \\
43\end{array}$ & $\begin{array}{l}0.1 \\
49\end{array}$ & $\begin{array}{l}0.1 \\
43\end{array}$ & $\begin{array}{l}0.1 \\
40\end{array}$ & $\begin{array}{l}0.1 \\
35\end{array}$ & $\begin{array}{l}0.1 \\
42\end{array}$ & $\begin{array}{l}0.1 \\
46\end{array}$ & $\begin{array}{l}0.1 \\
44\end{array}$ & $\begin{array}{c}0.1 \\
46\end{array}$ & $\begin{array}{c}0.1 \\
49\end{array}$ & $\begin{array}{l}0.1 \\
45\end{array}$ \\
\hline & $\begin{array}{l}400 \\
{ }^{\circ} \mathrm{C}\end{array}$ & $\begin{array}{c}0.11 \\
7\end{array}$ & $\begin{array}{c}0.13 \\
0\end{array}$ & $\begin{array}{l}0.1 \\
33\end{array}$ & $\begin{array}{l}0.1 \\
39\end{array}$ & $\begin{array}{l}0.1 \\
35\end{array}$ & $\begin{array}{l}0.1 \\
32\end{array}$ & $\begin{array}{l}0.1 \\
25\end{array}$ & $\begin{array}{l}0.1 \\
32\end{array}$ & $\begin{array}{l}0.1 \\
37\end{array}$ & $\begin{array}{l}0.1 \\
33\end{array}$ & $\begin{array}{l}0.1 \\
35\end{array}$ & $\begin{array}{l}0.1 \\
38\end{array}$ & $\begin{array}{l}0.1 \\
36\end{array}$ \\
\hline & $\begin{array}{c}600 \\
{ }^{\circ} \mathrm{C}\end{array}$ & $\begin{array}{c}0.10 \\
8\end{array}$ & $\begin{array}{c}0.11 \\
8\end{array}$ & $\begin{array}{l}0.1 \\
22\end{array}$ & $\begin{array}{l}0.1 \\
29\end{array}$ & $\begin{array}{l}0.1 \\
25\end{array}$ & $\begin{array}{l}0.1 \\
23\end{array}$ & $\begin{array}{c}0.1 \\
17\end{array}$ & $\begin{array}{l}0.1 \\
21\end{array}$ & $\begin{array}{l}0.1 \\
26\end{array}$ & $\begin{array}{l}0.1 \\
22\end{array}$ & $\begin{array}{l}0.1 \\
24\end{array}$ & $\begin{array}{l}0.1 \\
27\end{array}$ & $\begin{array}{l}0.1 \\
23\end{array}$ \\
\hline & $\begin{array}{c}800 \\
{ }^{\circ} \mathrm{C}\end{array}$ & $\begin{array}{c}0.09 \\
6\end{array}$ & $\begin{array}{c}0.10 \\
5\end{array}$ & $\begin{array}{l}0.1 \\
09\end{array}$ & $\begin{array}{c}0.1 \\
14\end{array}$ & $\begin{array}{c}0.1 \\
11\end{array}$ & $\begin{array}{l}0.1 \\
07\end{array}$ & $\begin{array}{l}0.0 \\
99\end{array}$ & $\begin{array}{l}0.1 \\
04\end{array}$ & $\begin{array}{c}0.1 \\
10\end{array}$ & $\begin{array}{l}0.1 \\
06\end{array}$ & $\begin{array}{c}0.1 \\
07\end{array}$ & $\begin{array}{c}0.1 \\
1\end{array}$ & $\begin{array}{l}0.1 \\
08\end{array}$ \\
\hline
\end{tabular}

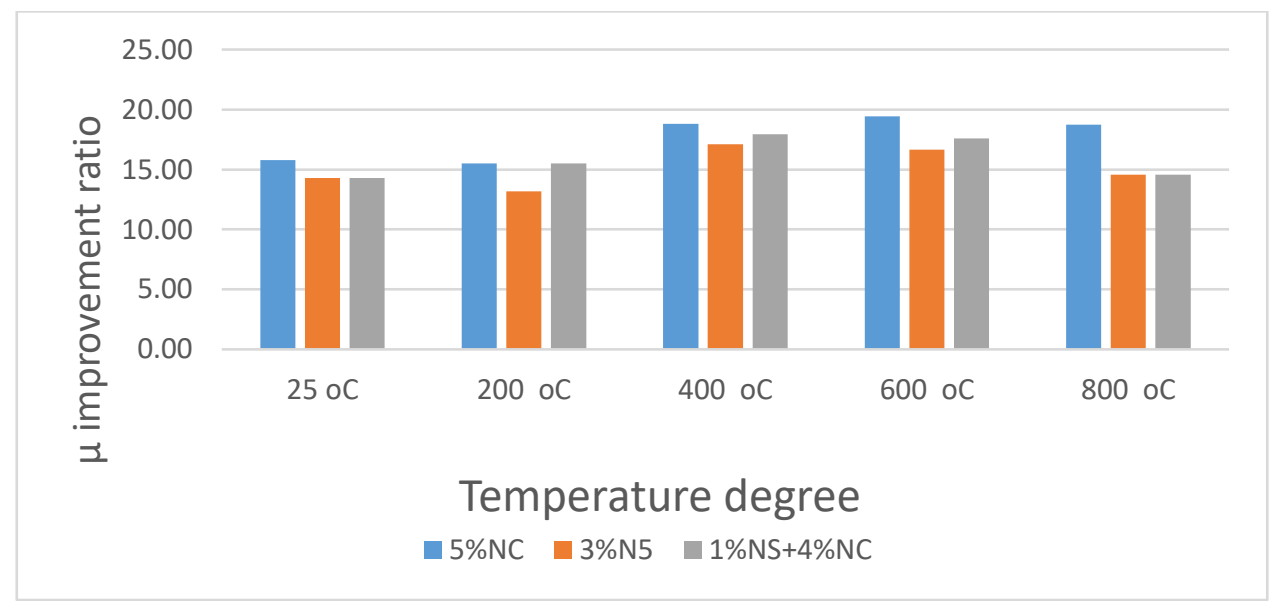

Figure (9) $\boldsymbol{\mu}$ improvement ratios according to optimum replacement values.

It's remarkable that Nanoclay is the most effective nano material for all temperature degrees in linear attenuation coefficient improving. This can be explained by nature of
Nanoclay that acts as a filler material which contribute to make the concrete shield denser and with less voids. This property enables the concrete shield to be more effective in resisting 
the radioactive waves such as gamma ray radiation. On the other hand, Nanosilica particles also have positive effect in $\mu$ improving. They act as a supplementary cementitious material and contribute in additional hydration activity and denser concrete. The hybrid mix effect lies in a moderate area between Nanosilica and Nanosilica.

\subsection{Visual observations of concrete samples after burning}

The following figures (10), (11), and (12) show the effect of fire exposure on concrete specimens at different temperature degrees. After twohours exposure, for all Nanoadditives specimens there was a little visible effect on the surface of heated specimens up to $400{ }^{\circ} \mathrm{C}$. Small cracks and partial spalling were when the temperature reached $600{ }^{\circ} \mathrm{C}$. It was observed that the aggregates decomposed and lost their integrity as the temperature reached $800{ }^{\circ} \mathrm{C}$.

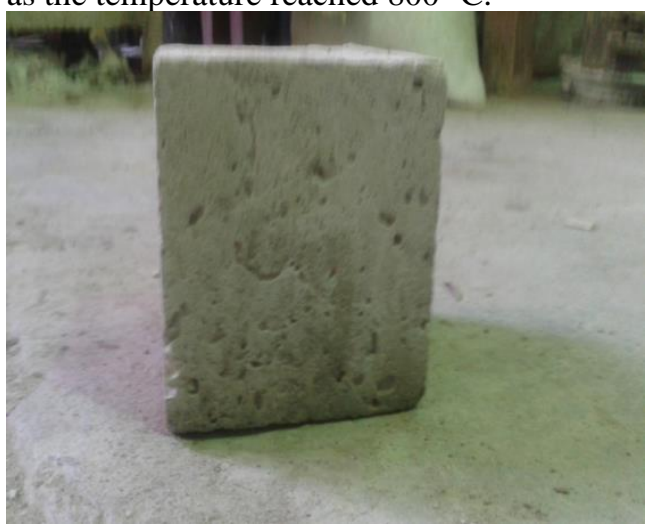

Figure (10) Nano silica specimen at $400{ }^{\circ} \mathrm{C}$

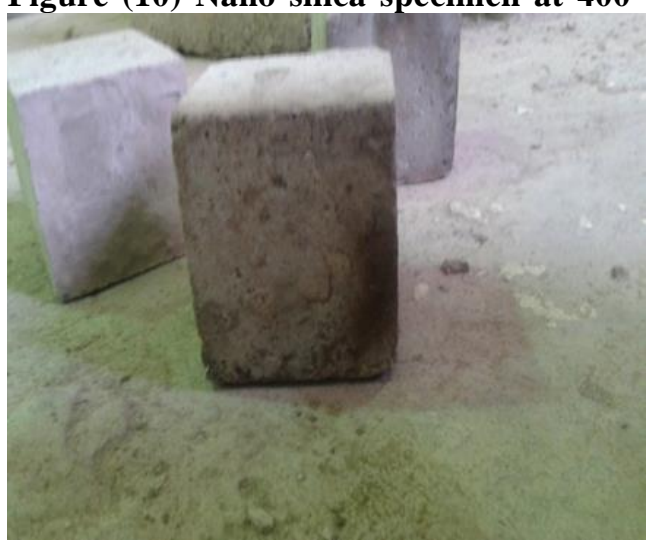

Figure (11) Nano clay specimen at $600^{\circ} \mathrm{C}$

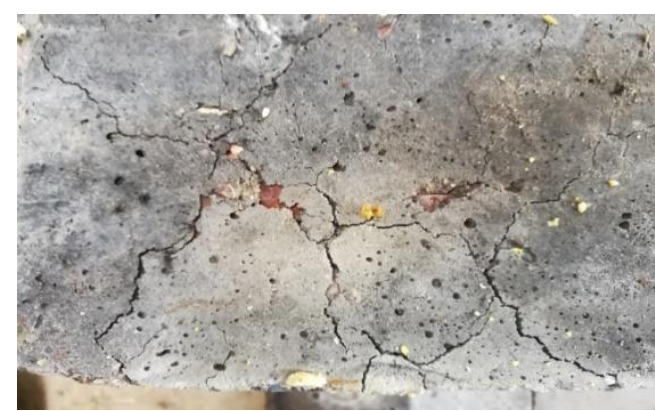

Figure (12) Hybrid mix specimen at $800{ }^{\circ} \mathrm{C}$ 5.Fuzzy Logic Systems model

\subsection{Fuzzy model structure}

In 1965, Lotfi Zadeh developed the Fuzzy set theory in order to deal with the imprecision and uncertainty that is often present in real world applications [14]. As previously mentioned, the general fuzzy Logic systems (FLS) consists of four components: fuzzification, fuzzy rule base, fuzzy output engine and defuzzification, while, input and output data can be added [15] as illustrated in Figure (13). The fuzzification process role is to convert the input data into different degrees of membership by a lookup in one or more several membership functions (simple linear functions, such as gauss or triangular ones, are preferable) [16,17]. All of the proposed membership functions in this study consist of three inputs (Nanoadditives type, Nanoadditives proportions, and Temperature degree). and one output (linear attenuation coefficient $\mu$ ). The membership function plots of input variables used in the training process are shown in Figure (14). Fuzzy rule base contains rules that include all possible fuzzy relation between inputs and outputs. These rules are expressed in the IF-THEN format [18]. Fuzzy output engine considers all the fuzzy rules in the fuzzy rule base and learns how to transform a set of inputs to corresponding outputs. The final step of defuzzification converts the resulting fuzzy outputs from the fuzzy output engine to a number [3]. 


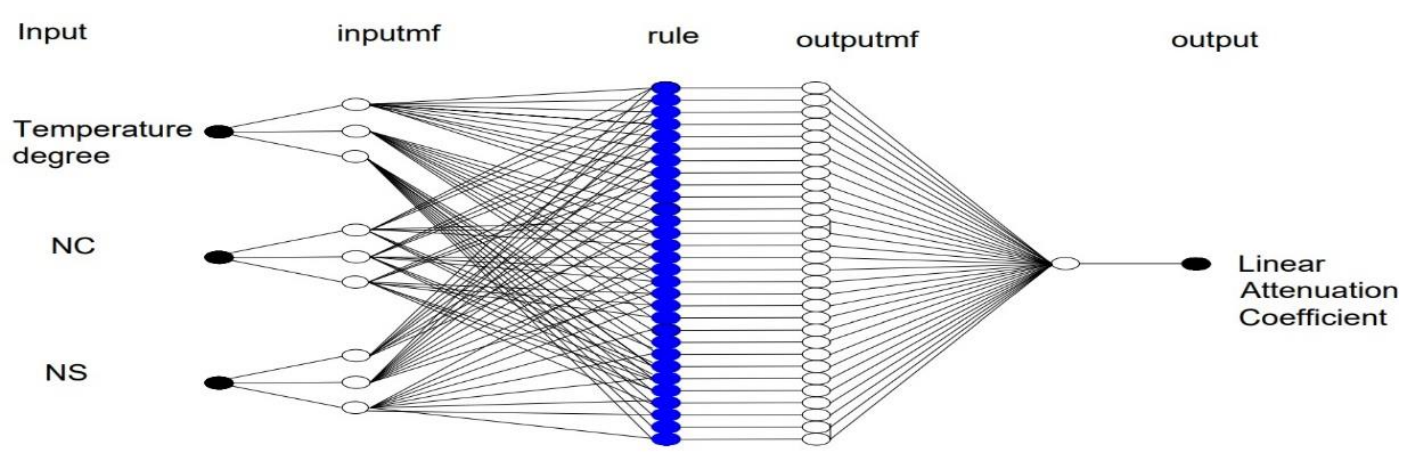

Figure (13) Structure of the FLS model
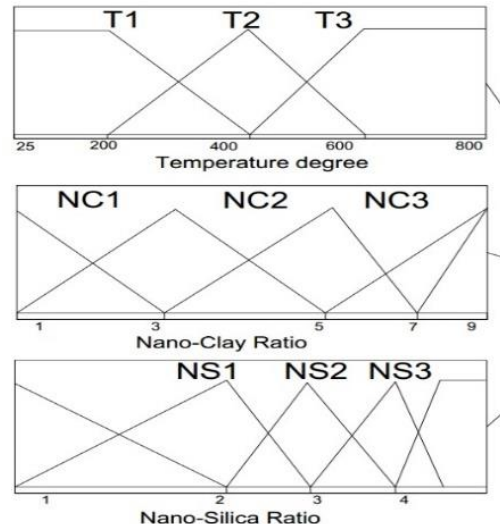

Fuzzy logic model

Figure (14) Block diagram of input variables used in the training process

\subsection{Simulation of FLS model and regression analysis.}

Parameter prediction is determination of aimed values response to evident input values of constituted model. For this aim, in the study 65 data of experiment results as reported in table (6) were used in the processes of fuzzy inference model in FLS. Five specimens results (shaded cells in table6) were omitted for use in the prediction process. Simulation and prediction results using FLS found to be very strong when compared to traditional linear regression analysis. The technique of regression depends on making the best fitting line through a big number of results, that line can represent the overall direction of results, and then the equation of the line can be concluded. Employing data of the 60specimens, the main deliverable of SPSS was the following empirical formula:

$\boldsymbol{\mu}=0.14501-5.16158 \mathrm{E}-05 \mathbf{X 1}+0.0011218 \mathbf{X 2}$ $+0.002068 \times 3$

Where: X1 represents temperature degree, X2 Nano clay ratio, and X3 represents Nano silica ratio. Table (9) showing all the expected $\mu$ values using FLS and linear regression analysis.

Table (9) Comparison of $\mu$ experimental data with FLS models and regression analysis results

\begin{tabular}{|c|c|c|}
\hline Experimental & FLS & $\begin{array}{c}\text { Regression } \\
\text { analysis }\end{array}$ \\
\hline 0.133 & 0.135775107 & 0.143721726 \\
\hline Experimental & FLS & $\begin{array}{c}\text { Regression } \\
\text { analysis }\end{array}$ \\
\hline 0.142 & 0.139001882 & 0.144843481 \\
\hline 0.147 & 0.148071115 & 0.147086992 \\
\hline 0.148 & 0.148063173 & 0.151574013 \\
\hline 0.144 & 0.144245546 & 0.153817523 \\
\hline 0.129 & 0.13084309 & 0.134688969 \\
\hline 0.139 & 0.135002404 & 0.135810724 \\
\hline
\end{tabular}




\begin{tabular}{|c|c|c|}
\hline \multicolumn{3}{|l}{} \\
\hline 0.143 & 0.144172562 & 0.138054235 \\
\hline 0.149 & 0.147760299 & 0.140297745 \\
\hline 0.143 & 0.143594524 & 0.142541255 \\
\hline 0.14 & 0.139673978 & 0.144784766 \\
\hline 0.13 & 0.130243557 & 0.125487573 \\
\hline 0.133 & 0.134322911 & 0.127731083 \\
\hline 0.139 & 0.13893175 & 0.129974594 \\
\hline 0.135 & 0.13705421 & 0.132218104 \\
\hline 0.132 & 0.130651658 & 0.134461615 \\
\hline 0.108 & 0.109647911 & 0.114042667 \\
\hline 0.118 & 0.115708399 & 0.115164422 \\
\hline 0.122 & 0.121919495 & 0.117407932 \\
\hline 0.129 & 0.126587627 & 0.119651443 \\
\hline 0.125 & 0.125480474 & 0.121894953 \\
\hline 0.123 & 0.123126964 & 0.124138464 \\
\hline 0.096 & 0.097556773 & 0.103719515 \\
\hline 0.105 & 0.102174357 & 0.104841271 \\
\hline 0.109 & 0.110682533 & 0.107084781 \\
\hline 0.114 & 0.115335945 & 0.109328292 \\
\hline 0.111 & 0.110463834 & 0.111571802 \\
\hline 0.107 & 0.107132199 & 0.113815313 \\
\hline 0.139 & 0.138935012 & 0.145790038 \\
\hline 0.147 & 0.146755344 & 0.14785835 \\
\hline 0.152 & 0.152296086 & 0.149926662 \\
\hline 0.135 & 0.134941171 & 0.136757281 \\
\hline 0.142 & 0.142093659 & 0.138825593 \\
\hline 0.146 & 0.145277179 & 0.140893905 \\
\hline 0.144 & 0.144800361 & 0.142962217 \\
\hline 0.132 & 0.13298104 & 0.128502442 \\
\hline 0.137 & 0.136293298 & 0.130570754 \\
\hline 0.133 & 0.133781505 & 0.132639066 \\
\hline 0.117 & 0.117112715 & 0.116110979 \\
\hline 0.121 & 0.119121733 & 0.118179291 \\
\hline 0.126 & 0.126589916 & 0.120247603 \\
\hline 0.122 & 0.12172182 & 0.122315915 \\
\hline 0.099 & 0.098768561 & 0.105787828 \\
\hline 0.104 & 0.105030298 & 0.10785614 \\
\hline 0.11 & 0.109495221 & 0.109924452 \\
\hline 0.106 & 0.106441192 & 0.111992764 \\
\hline 0.15 & 0.150564617 & 0.153590008 \\
\hline 0.152 & 0.151065844 & 0.15311673 \\
\hline 0.148 & 0.148349911 & 0.152643451 \\
\hline 0.146 & 0.146528711 & 0.144557251 \\
\hline 0.149 & 0.146789877 & 0.144083972 \\
\hline Experimental & FLS & Regression \\
\hline 0.145 & 0.146379401 & 0.143610694 \\
\hline 0.135 & 0.134990627 & 0.1342341 \\
\hline 0.138 & 0.136833486 & 0.133760821 \\
\hline 0.123 & 0.136903905 & 0.133287543 \\
\hline & 0.124082305 & 0.123910949 \\
\hline & 0.122985318 & 0.122964392 \\
\hline & \\
\hline
\end{tabular}

\begin{tabular}{|c|c|c|}
\hline 0.107 & 0.107372137 & 0.113587798 \\
\hline 0.11 & 0.108793115 & 0.113114519 \\
\hline 0.108 & 0.108693061 & 0.112641241 \\
\hline
\end{tabular}

To assess the goodness -of-fit of the developed formula, the coefficient of determination $\left(\mathrm{R}^{\wedge} 2\right)$ and the standard error of estimate are the most widely used statistics for this purpose. In this analysis, $\left(\mathrm{R}^{\wedge} 2\right)$ associated with the equation fitted is equal to (0.909) as shown in figure (15). While $\left(\mathrm{R}^{\wedge} 2\right)$ value for the FLS found to be (0.993) which represents an extremely accurate and superior value as shown in figure (16).

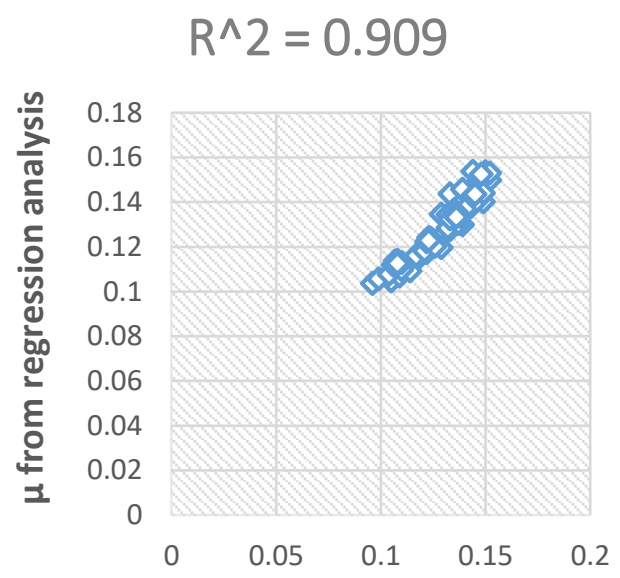

Linear attenuation coefficient $\mu$

Figure (15) Regression Plot for the predicted values of $\mu$ using the developed empirical formula.

$$
R^{\wedge} 2=0.993
$$

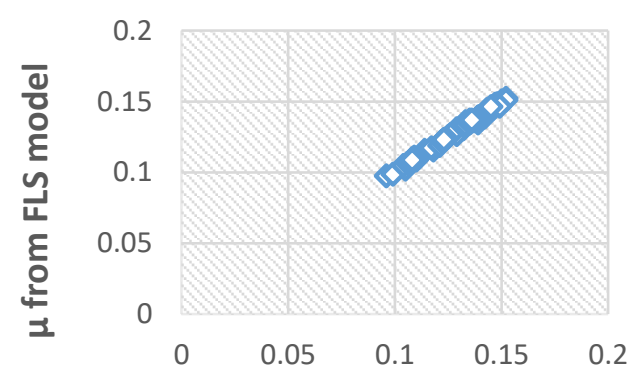

Linear attenuation coefficient $\mu$

Figure (16) Regression Plot for the predicted values of $\mu$ using FLS 


\section{3 prediction process using FLS.}

Data of 5 specimens randomly selected, as shaded in table (6), were reserved so that they are employed to assess and verify the proposed model. Using data (values of input variables and the corresponding experimental results of $\mu$ ) of the 5 reserved specimens, the proposed FLS model is assessed for its efficiency in accurately simulating the linear attenuation coefficient $(\mu)$ after fire exposure. In other words, the developed FLS model is assessed by comparing experimental results and simulated (predicted) values with one another for 5 specimens reserved to this end. The results of the comparison provided in table (10) showing strong accuracy and high efficiency.

Table (10) Simulation results for the reserved five specimens for $\mu$ prediction model.

\begin{tabular}{|c|c|c|c|c|c|}
\hline Sample & $\mathbf{1}$ & $\mathbf{2}$ & $\mathbf{3}$ & $\mathbf{4}$ & $\mathbf{5}$ \\
\hline $\begin{array}{c}\text { Temperat } \\
\text { ure degree }\end{array}$ & 25 & 400 & 25 & 400 & 600 \\
\hline $\mathbf{N C}(\%)$ & 5 & 0 & 0 & 0 & 1 \\
\hline NS (\%) & 0 & 0 & 4 & 1 & 4 \\
\hline $\begin{array}{c}\boldsymbol{\mu} \\
\begin{array}{c}\text { experimen } \\
\text { tal results }\end{array}\end{array}$ & $\begin{array}{c}0.15 \\
4\end{array}$ & $\begin{array}{c}0.11 \\
7\end{array}$ & $\begin{array}{c}0.14 \\
9\end{array}$ & $\begin{array}{c}0.12 \\
5\end{array}$ & $\begin{array}{c}0.12 \\
7\end{array}$ \\
\hline $\begin{array}{c}\text { FLS } \\
\text { predicted } \\
\text { values }\end{array}$ & $\begin{array}{c}0.15 \\
2\end{array}$ & $\begin{array}{c}0.11 \\
6\end{array}$ & $\begin{array}{c}0.14 \\
8\end{array}$ & $\begin{array}{c}0.12 \\
8\end{array}$ & $\begin{array}{c}0.12 \\
7\end{array}$ \\
\hline
\end{tabular}

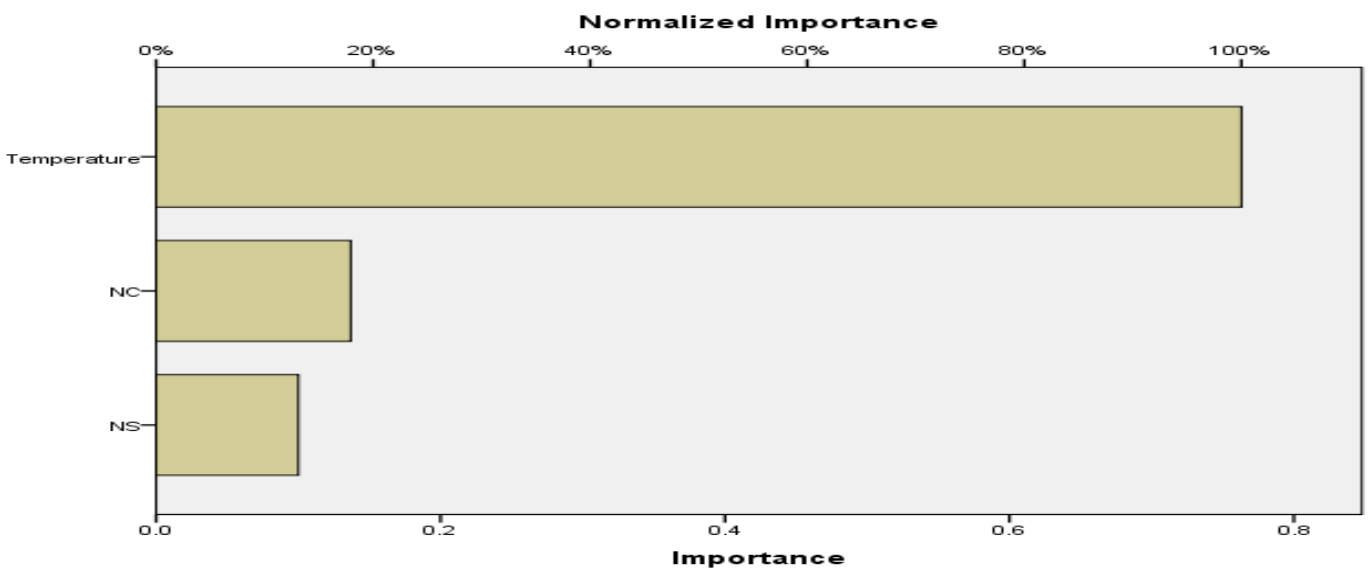

Figure (17) Relative importance of input parameters

\subsection{Sensitivity Analysis}

Sensitivity Analysis (SA) can be explained as how much the model response is influenced by changes in the model input parameters [19]. Generally, the accuracy of the outputs prediction is highly dependent on the number of input variables. In other words, the more the number of input parameters are, the more accurate the results of the predictor models would be [6]. Results of Sensitivity Analysis are summarized in table (11) and figure (17). Results show that temperature degree has the most impact on $\mu$. In addition, $\mu$ is influenced by levels of Nanoclay more than those of Nano silica.

Table (11) Independent Variable Importance for RCS prediction model

\begin{tabular}{|c|c|c|c|}
\hline Variable & Temperature & NC & NS \\
\hline Importance & .763 & .137 & .1 \\
\hline $\begin{array}{c}\text { Normalized } \\
\text { Importance }\end{array}$ & $100.0 \%$ & $17.9 \%$ & $13.1 \%$ \\
\hline
\end{tabular}




\section{Conclusion}

According to the results of both the experimental investigation and the developed Fuzzy Logic systems model, the following points could be concluded:

1- Nanomaterials used in this study (Nanoclay, Nanosilica, and hybrid mix of both) lead to obvious improvement in linear attenuation coefficient values for the different concrete mixes either at room temperature conditions or after elevated temperature exposure.

2- Improvement rates in linear attenuation coefficient values are influenced by type and proportion of Nanomaterials used in this study. 3- After two hours of fire exposure at $800^{\circ} \mathrm{C}, \mu$ value of the control mix was reduced by $27.82 \%$. The addition of $5 \% \mathrm{NC}$ could reduce that ratio to the level of $14.28 \%$, while improvement ratios of $(15.8 \%, 14.3 \%$, and $14.3 \%)$ were recorded comparing with the control mix for the optimum nano replacement ratios at $5 \% \mathrm{NC}, 3 \% \mathrm{NS}$, and $(1 \%+4 \%)$ for the hybrid mix.

4- Linear attenuation coefficient values are influenced by levels of Nanoclay more than those of Nanosilica according to sensitivity analysis results.

5-In general, complex nonlinear behavior of concrete can be effectively processed using Fuzzy Logic Systems model, while the current study verified the high accuracy of FLS in $\mu$ values simulation before and after fire exposure. 6- Statistical technique of regression analysis was performed in order formulate mathematical prediction equation of $\mu$ values with acceptable regression value of 0.909 .

7- Prediction results provided by simulation of linear attenuation coefficient values using the developed FLS model is found superior compared with regression analysis.

\section{References}

[1] A.A. Elsayd, I.N. Fathy. Experimental Study of Fire Effects on Compressive Strength of Normal-Strength Concrete Supported with Nanomaterials Additives. IOSR Journal of Mechanical and Civil Engineering (IOSR-JMCE), p-ISSN: 2320334X, Volume 16, Issue 1 Ser. III (Jan. - Feb. 2019), PP 28-37.
[2] Tanyildizi, Harun. Fuzzy logic model for prediction of mechanical properties of lightweight concrete exposed to high temperature. Materials and Design 30 (2009) 2205-2210.

[3] Akkurt, S., Tayfur, G., Can, S. Fuzzy logic model for the prediction of cement compressive strength. Cement and Concrete Research 34 (2004) 1429-1433.

[4] Freedman, David. A. (27 April 2009). Statistical Models: Theory and Practice. Cambridge University Press. ISBN 978-1-13947731-4.

[5] Cook, R. Dennis\& Weisberg, Sanford. Criticism and Influence Analysis in Regression, Sociological Methodology, Vol. 13. (1982), pp. 313-361.

[6] Faezehossadat. K, Mahmoud. A, et al. Multiple linear regression, artificial neural network, and fuzzy logic prediction of 28 days compressive strength of concrete. Front. Struct. Civ. Eng. 2017, 11(1): 90-99. DOI 10.1007/s11709-016-0363-9.

[7]. ESS. Egyptian Standard Specifications, cement physical and mechanical test. (47561/2009)

[8]. ECP. Egyptian Code for Design and Execution for Concrete Structures. (No. 203; 2007)

[9] ESS. Egyptian Standard Specifications, concrete aggregates from natural sources. (1109/2002)

[10] Heikal, M., Ali A.I., Ismail, M.N. and Ibrahim, S.A.N.S., Behavior of composite cement pastes containing silica nano-particles at elevated temperature. Construction and Building Materials, vol. 70, No. 0, 2014, pp. 339-350

[11] Hela, R., and Marsalova, J. Possibilities of Nanotechnology in Concrete.3rd International Conference on Nano-Technology in Construction (NTC 2011), Cairo, Egypt, April 2011.

[12] Heikal M., Ali A.I., Ismail M.N. and Ibrahim S.A.N.S., "Behavior of composite cement pastes containing silica nano-particles at elevated temperature", Construction and 
Building Materials, vol. 70, No. 0, 2014, pp. 339-350.

[13] Morsy, M. S., Al-Salloum, Y. A., Abbas, H., \& Alsayed, S. H. (2012). "Behavior of blended cement mortars containing nanometakaolin at elevated temperatures". Construction and Building materials, 35, pp.900-905.

[14] Zadeh LA. Fuzzy set. Inform Control 1965; 8:338-53.

[15] Mustafa. S, _Ilker. B, et al. Prediction of long-term effects of GGBFS on compressive strength of concrete by artificial neural networks and fuzzy logic. Construction and Building Materials 23 (2009) 1279-1286.
[16] Demir F. A new way of prediction elastic modulus of normal and high strength concrete-fuzzy logic. Cement Concrete Res 2005;35(8):1531-8.

[17] Fa-Liang G. A new way of predicting cement strength-fuzzy logic. Cement Concrete Res 1997;27(6):8838.

[18] I.B. Topc, M. Sarıdemir. Prediction of compressive strength of concrete containing fly ash using artificial neural networks and fuzzy logic. Computational Materials Science 41 (2008) 305-311.]

[19] Vu-Bac N, Silani M, Lahmer et al. A unified framework for stochastic predictions of mechanical properties of polymeric nanocomposites. Computational Materials Science, 2015, 96: 520-535. 


\section{التنبؤ بمعامل التهوين الخطى لأشعة جاما لانواع مختلفة من خرسانات النانو باستخدام الأكاء الصناعى}

يعد تصميم وانشاء المبانى المقاومة للاشعاع بغرض حماية الناس والمعدات من تأثيراته الضارة واحداً من اكبر التحديات التى تواجه

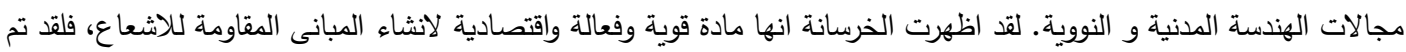

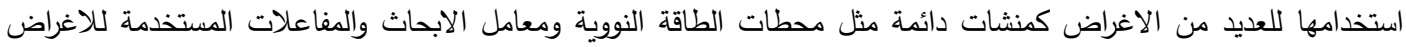
البحثية. هنالك تنوع كبير فى المواد التى تستخدم فى الخلطات الخرسانية المعدة لانتاج خرسانات مقاومة للاشعاع والتى يكون

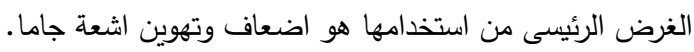

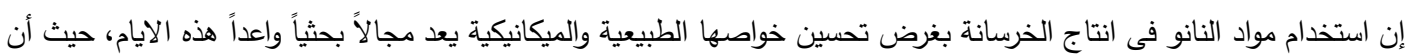

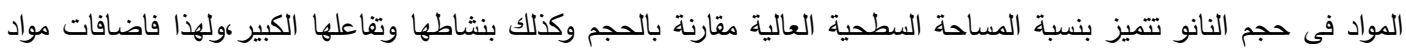

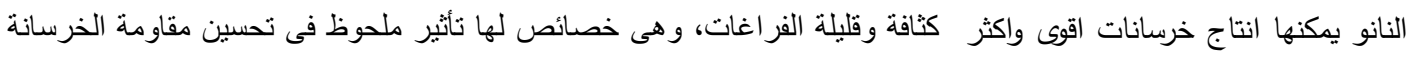

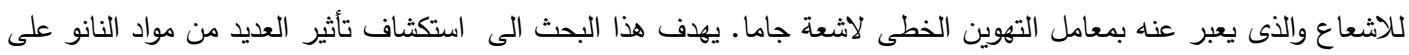
مقاومة الخرسانة للاشعاع وعلى خصائصها كدرع واقى من الاشعاع وهى مواد (نانو السيليكا-نانو الطين-خليط من كلا المادتين).

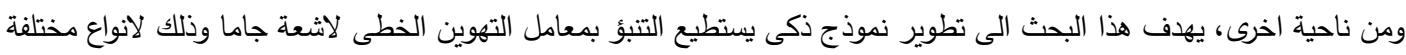
من الخرسانات وبنسب اضافات مختلفة لمواد النانو، ولهذا فان الدراسة تعتمد على استخدام نماذج المنطق الضئ الضبابى كأحد اهم وسائل

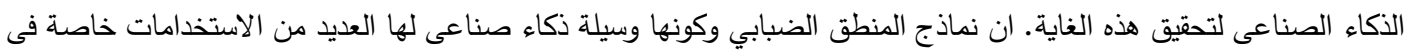

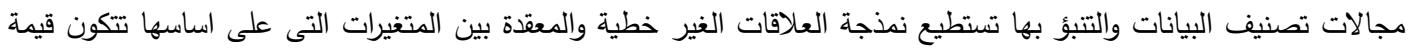

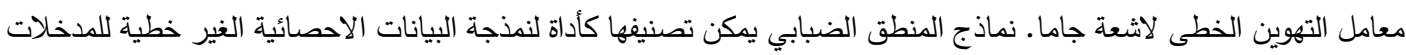

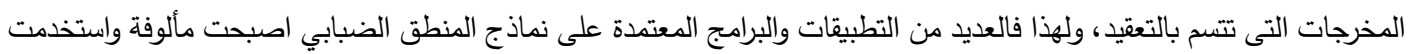
فى العديد من الابحاث السابقة وفى مجالات هندسية متعددة. تحتاج نماذج المنطق الضبابي الى كم كافى من البيانات لتعمل

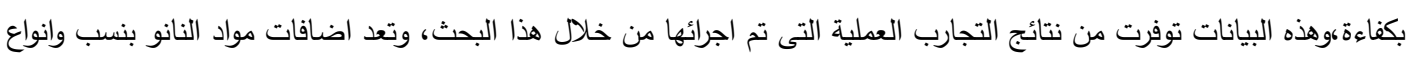

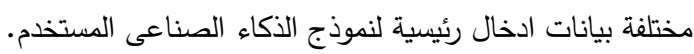

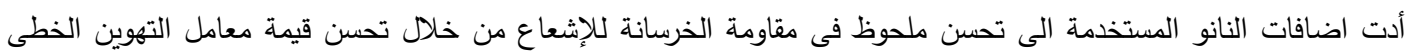

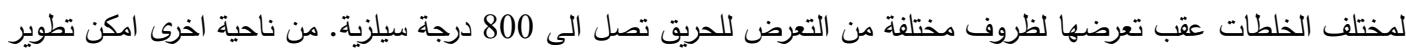

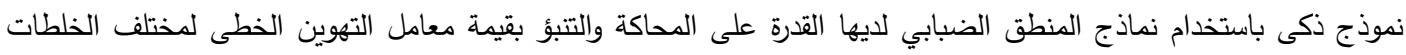
الخرسانية 